\title{
Prophetic Education at Pesantren As A Efforts To Prevent Religious Radicalism
}

\author{
Dimas Indianto S1, Sunhaji ${ }^{2}$, Intan Nur Azizah ${ }^{3}$, Akhmad Roja Badrus Zaman ${ }^{4}$ \\ 1,2,3 Prof. KH. Saifuddin Zuhri State Islamic University Purwokerto, Banyumas, Indonesia \\ 4 Sunan Kalijaga State Islamic University Yogyakarta, Yogyakarta, Indonesia
}

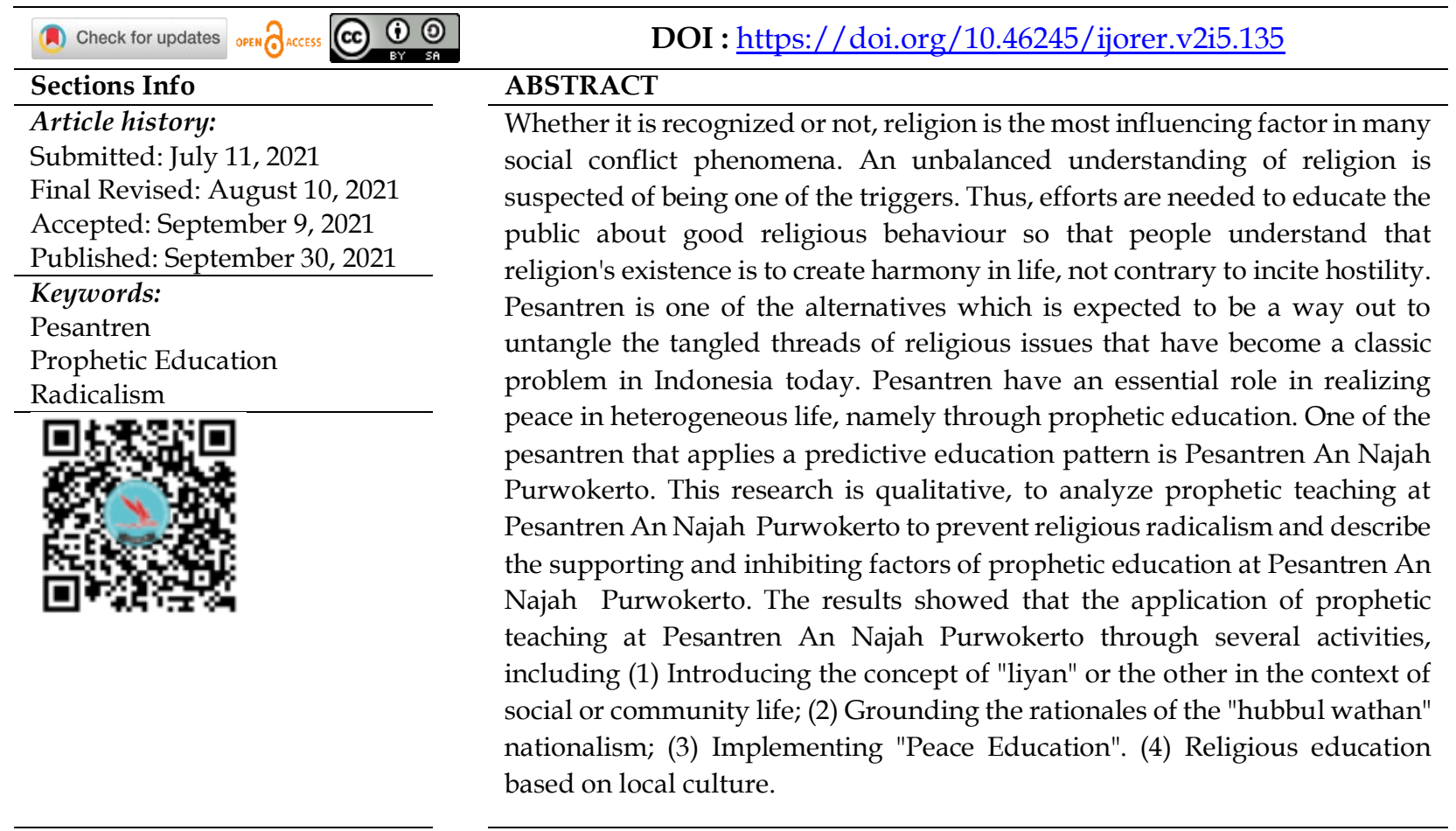

\section{INTRODUCTION}

The practice of violence (both physical and symbolic violence, borrow the term Pierre Bourgeou) in the name of religion, from fundamentalism, radicalism to terrorism, has recently become more prevalent. The unity of the nation is currently being tested for its existence. Various indicators that show signs of national division are apparent. From the ideological-practical understanding, religion should motivate humanity always to uphold peace and improve the welfare of all the ummah on this earth as a manifestation of Islam rahmatan lil Alamin. However, religion has become one of the causes of humankind violence and destruction. Therefore, preventive measures are needed so that the problem of religious conflict can be minimized again in the future. Current and future religious radicalism and extremism are predicted to still occur because the root causes are still there, both ideological and political factors (Alkatiri, 2018).

Recently, the issue of radicalism has become more prevalent in Indonesia (Asrori, 2015). There have been many phenomena that have resulted from a superficial understanding of diversity. Many people are trapped in truth claims and alienate them from different or "liyan". This partial understanding of religion must be complete immediately through education that teaches the importance of the spirit of respecting 
differences and upholding tolerance in the name of respect for diversity (Zaini, 2018). In relation to the urgency of education, Helmy quoted a sentence conveyed by Malala Yousafzai, a 2014 Nobel laureate for peace, "with the guns you can kill terrorist, with education you can kill terrorism". From this is born a collective awareness that education can solve to the root of problems, not just what appears on the surface, as in this case the understanding of radicalism or fundamentalism.

Religious education should be for the developing universal morality (Wajdi et al., 2021), means that exist in religions and develops an inclusive and pluralist theology (Ainiyah and Wibawa, 2013). In this regard, educational institutions in multicultural societies need to teach peace and conflict resolution (Eriyanto et al., 2021), such as those in prophetic education.

Prophetic education has a foundation of conducive academic and milieu traditions, with solid transcendence pillars (Miftahulloh, 2017). It will affect all dimensions and the education system. In its application, the posts of humanization and liberation accompany it (Roqib, 2016), so that education must return to its prophetic mission. They are humanizing humans (humanization), doing ijtihad (freedom), and human faith (transcendence).

One of the pesantren that applies prophetic education is Students Pesantren of An Najah Purwokerto. It is evidenced by; first, a prophetic mission is the basis of the curriculum, which can be seen on the santri card, namely the pesantren's vision and mission column. Second, Pesantren An Najah Purwokerto is academics who pioneered the theoreticalpractical prophetic education, so that he is a charismatic cum prophetic Kyai-- Kyai Kharismatik cum Prophetic is the term used in K.H.'s biography. Moh Roqib, M.Ag, who is currently the Rector of IAIN Purwokerto as well as the chairman of FKUB Banyumas (Indianto, 2019). With that in mind, this study seeks to reveal the Prophetic Pesantren and the Efforts to Prevent Religious Radicalism.

\section{METHOD}

This research is field research (field research) with qualitative methods, namely studying the latest status and environmental interactions in an institutional unit. This study analyzes prophetic education at Pesantren An Najah Purwokerto to prevent religious radicalism and describes the supporting and inhibiting factors of prophetic teaching at Pesantren An Najah Purwokerto.

This research uses interview, observation, and documentation methods. The interview method is to obtain information by asking research subjects, who took part in the Prophetic Education at Pesantren An Najah Purwokerto. The interview method is to determine the basic concepts of Prophetic Education at Pesantren An Najah Purwokerto to prevent religious radicalism, about Kyai and pesantren's role in grounding the values of prophetic education as an effort to stop religious radicalism. The observation method is to obtain data related to the physical condition (building, geographical location) of Students Pesantren An Najah's facilities and infrastructure, curriculum, and other matters related to grounding prophetic education values. It is an effort to prevent religious radicalism in Pesantren An Najah Purwokerto. Simultaneously, the documentation method is to obtain written and documented data such as pesantren profiles, the applied curriculum, data on madrasah activities, and data that support strategic activities for implementing Prophetic Education at Pesantren An Najah Purwokerto. 
The data analysis in this study used an integralist approach in seeing the strategy for applying Prophetic Education at Pesantren An Najah Purwokerto. This analysis refers to the data found in the field data, namely the Prophetic Education concept at Pesantren An Najah Purwokerto to prevent religious radicalism.

\section{RESULTS AND DISCUSSION}

\section{Radicalism}

The word radicalism in terms of terminology comes from the root word radix, which means root (tree) (Rodin, 2016) . This word can be developed into a radical word, which is an adjective. So, it is a flash that people who think radically must have a more detailed and deep understanding, just like the roots above, as well as persistence in defending their beliefs (Haryanto, 2016). After that, the addition of the suffix -ism itself gives meaning to a view of life (paradigm), an understanding, and beliefs or teachings. Its use is also often associated with a particular sect or belief. The emergence of the radicalism movement and the birth of the fundamentalism group were caused by two factors. First, the internal factor, the legitimacy of the religious text, in carrying out the "resistance" it is often using text legitimacy (both religious and "cultural" texts) as a support. For the case of the "Islamic extremism" movement that has spread in almost all areas of Islam (including Indonesia) also uses Islamic texts (Al-Qur'an, hadith, and classical sourcesKitab Kuning) as the basis for theological legitimacy, because these texts are textually supportive of exclusivism and extremism. Second, external factors. among them: first, from the political-economy aspect, the government's depostic power deviates from the fundamental values of Islam. Second, the cultural factor, this factor emphasizes the western culture that dominates life today, the culture of secularism which is considered a great enemy that must be eliminated from the earth. Third, the socio-political factors, the government which is not firm in controlling the terrorist problem can also be used as one of the factors in the rampant radicalism among Muslims.

The radical group has characteristics, among others (Masduqi, 2013); first, they often claim a single truth and mislead other groups who disagree. Claims of truth always arise from those who seem like they are prophets who never make mistakes (ma'sum), even though they are only human (Naupal, 2014). Truth claims cannot be justified because humans have relative truth, and only Allah knows the absolute truth (Fauzi, 2018). Therefore, if a group feels self-righteous, they immediately act arrogantly, seizing Allah's authority.

Second, radicalism makes it difficult for Islam, which is light by considering sunnah worship as obligatory and makruh as if it is haram (Alim et al., 2018). The characteristic of radicalism is religious behaviour that prioritizes secondary problems and overrides primary ones. Third, radical groups are mostly excessive in religion which is not appropriate. In preaching, they put aside the Prophet's gradual methods so that their da'wa made ordinary Muslims feel afraid and objected. Even though Q.S. Al-Hajj: 78 has confirmed that Allah wants things that light up and does not want things that are burdensome for His people (Rizqa, 2020).

Fourth is rough-in interaction, loud in speaking and emotional in da'wa. This da'wa's characteristics are contrary to the politeness and gentleness of the Prophet's da'wa in the Q.S. 3: 159. In QS. 16: 125, Allah also advised Muslims to do da'wa politely and avoid harsh words. Fifth, radical groups easily prejudice others outside their group. They always look at others only from the negative aspects and ignore the positive aspects 
(Khamid, 2016). Muslims must avoid this matter because the root of radicalism is prejudice against others. Having a bias is a form of condescending to other people. Radical groups often appear to feel holy and consider other groups to be bid'ah and heretics ( $\mathrm{Mu}^{\prime}$ awwanah, 2018).

Sixth, it is easy to ignore other people who have different opinions. In classical times this attitude was identical to the Khawarij group, then in contemporary times, it was like Jamaah Takfir wa al-Hijrah and other puritan groups (Anis, 2016). This group disbelieves other people who commit immorality, disbelieves the government that adheres to democracy (Najib and Humaidi, 2020). They deny people who are willing to implement democracy, disbelieve Muslims in Indonesia who uphold local traditions and disbelieve all people who differ from them because they believe that their opinion is Allah.

\section{Prophetic Education at Pesantren}

The term prophetic pesantren has not been commonly used among academics and pesantren practitioners. However, a prophetic pesantren is a pesantren that bases its curriculum on prophetic values, namely transcendence, humanism, and liberation. All three are essential pillars in prophetic education. Definitively, prophetic teaching can is as a set of theories that describe and transform social phenomena. It does not change things for the sake of change but is expected to lead to change based on ethical and prophetic ideals, namely guided by - as in verse 110 Surat Ali-Imran - three elements to watch out for. First, al-amr bil-ma'ruf, is humanized. Second, al-nahy anil Munkar has the character of liberation. Third, tu'minuna billah is transcendent. You are the best people who were born to mankind, ordered the ma'ruf, prevented the evil, and believe in Allah "Q.S. Ali Imran 110. According to Kuntowijoyo, in his theory of Social Profetic Sciences, the above verse contains three things, namely humanization, liberation, and transcendence. These three factors characterize prophetic social science which is directed towards engineering society towards future socio-ethical ideals.

Prophetic education is an educational process that is carried out as in the prophetic era. Education integrates physical and spiritual aspects between the world and the hereafter (Akmansyah, 2016). So, prophetic education is an institution for maturing a religious humanization process (Widiyanto, 2017). For this reason, prophetic education is a process of transferring knowledge and values that aim to get closer to Allah and nature and understand it to build an ideal social community (khairul ummah) (Roqib, 2016). Prophetic education seeks to present prophetic values in the contemporary context.

In implementing prophetic values, prophetic pesantren prioritize solution-based discourse based on theological foundations whose legal sources (al-Qur'an and alHadith) are as follows:

a. Islam commands its people to interact, especially with Christianity and Judaism and can explore religious values through intellectual and theological discussions and debates together in the best possible way. (Q.S. Al-Ankabut: 46).

b. Plurality is an objective reality of the human community. Allah affirmed: "People, we created you from a man and a woman and made you nations and tribes so that you would know each other. Surely the noblest among you in the sight of Allah is the most pious among you. Allah is All-Understanding, All-Knowing." (Q.S. Al-Hujurat: 13).

c. Islam commands its people to interact, especially with Christianity and Judaism and can explore religious values through intellectual and theological discussions and debates together in the best possible way. (Q.S. Al-Ankabut: 46). 
d. Al-Qur'an rebuked Prophet Muhammad when he showed a passionate desire to force people to accept and follow the teachings he conveyed, as follows: "If your God wills, then, of course, the people on this earth will believe. So, do you want to force humans beyond their willingness? (Q.S., 10:99).

In looking at heterogeneity, plurality, and multiculturalism, prophetic pesantren emphasizes human beings' basic nature by not leaving anything aside from their existence. These values include (Roqib, 2016):

a. Upholding the values of humanity/humanity

b. Religious freedom for the community

c. Democracy in all aspects of the social order

d. Tolerance between humans,

e. Reconciliation/peace on earth

f. Love, compassion, help each other, protect each other and give safety

g. Justice / equality / egalitarianism

h. Social benefit

i. Preservation of society cultures

These values are then derived into a prophetic curriculum with several approaches; they are (Miftahulloh, 2017):

a. Habit, carry out learning by getting used to good attitudes and behaviour, especially those related to the values of tolerance, love, and help.

b. Rational, enabling students' ratio, so that the content and values implanted are easy to understand by reasoning.

c. Emotional, trying to arouse students' feelings in understanding the reality of cultural and religious diversity in society.

d. Functional, to function the teachings of each religion, especially the importance of appreciating differences by emphasizing the benefits and wisdom for students in everyday life with their level of development.

\section{Pesantren An-Najah as an Image of Prophetic Pesantren}

1. Internalization of Prophetic Logic

In the practice of prophetic education, Pesantren An Najah Purwokerto implements several steps; this considers several efforts that, according to Mujiburrahman, educational institutions can do to internalize the values of plurality, including (Roqib, 2016):

a) Developing the rationalization of educational institutions' management with religious education, from government, fundraising, curriculum development, syllabus to program implementation.

b) doing cooperation with those previously considered as rivals or enemies.

c) standardizing religious teachings by the needs of the people it serves.

d) giving a broader role to those who have been considered non-specialists in spiritual matters.

2. The strategy of establishing prophetic logic prophetic

In developing its curriculum, Pesantren An Najah Purwokerto, in its efforts to ground prophetic reasoning, has three main methods, namely: 
a) Revolutionary strategy, by conditioning the ideology of multiculturalism and pluralism through the curriculum of religious education materials in pesantren.

b) The strategy of exile is by creating fortresses by building subcultures through educational institutions managed explicitly by religious institutions such as Islamic, Catholic, and Protestant schools.

c) Dialogue strategy is the courage to face diversity and dialogue with people who disagree with the ideology of multiculturalism and pluralism.

3. Guidance in forming the prophetic based curriculum

The first steps taken by the guidelines and creating an educational curriculum with a prophetic perspective include the following:

a) Curriculum development must be based on faith in God Almighty, absolute norms or values taken from the world's major religions and the integral relationship between God, humans, and nature.

b) Because knowledge comes from God, humans are not (the creators of experience) or the makers of that knowledge. And this is because humans can easily find aspects of this world. Thus, human values can be inseparable in selecting, investigating, and accepting the truth.

c) Students (santri) are required to know the hierarchy between science and values. Knowledge is obtained through an experience that must submit to rational understanding, and proper knowledge must submit to religious norms that come from God.

d) Faith and values must be recognized as the basis of human culture. Therefore, the two must be inseparable in the teaching and learning process. Science does not have to be shown to be contrary to religious views. Thus, in education, it must be used to encourage "values" or good values.

e) Humans cannot know the absolute truth, but truth can be realized at different levels through feelings, thoughts, intuition, and intellect. These four forms must work in harmony and be integrated into a comprehensive education system.

f) Students (santri) must be encouraged to know the principles of unity and diversity and realize the fundamental similarities that penetrate the biological and psychological world. It is a reflection on the agreement of regulations for the creation of the world. The world is a system that unites (the universe is a unified system) and an integral relationship between the different parts.

4. A prophetic learning approach

Teaching approaches, such as teaching methods, need to be considered to lead to education with a prophetic perspective apart from the curriculum aspects that must be designed. Pesantren An Najah Purwokerto, in this case, applies a prophetic learning approach as follows (Miftahulloh, 2017):

a) Educators (ustadz) must form students' mindset (santri) openly to accept other truths, apart from those already believed. Therefore, we must avoid conveying Islamic messages in an ideological-doctrinal way to promote truth claims in religion.

b) Educators (ustadz) must be able to form students' mindset to appreciate differences. Sincerely, communicatively, inclusively, and not be suspicious of each other. Therefore, we must avoid conveying Islamic understanding, which only rests on textual-normative. 
c) Educators (ustadz) in delivering educational material must be honest and transparent so that students (santri) can understand Islamic education material in practical life. Educators should not position themselves as agents/distributors of certain schools of thought by blaming other schools of thought.

d) Educators (ustadz) should understand that in Islamic education, it is not only the transfer of knowledge (transfer of knowledge) but also the transfer and internalization of values (transfer and internalization of values) within students.

e) Educators (ustadz) need to familiarize children with cross-cultural exchanges with fellow students. This experience will be able to help them to understand other people in a difference.

Prophetic Education Portraits in Pesantren An-Najah Purwokerto as an Effort To Prevent Religious Radicalism

Religious education, which should have been directed to be a media of awareness for the people, has maintained an impression of exclusivity (Fuad, 2014). That way, an understanding that is not inclusive will grow so that the harmonization of religions in people's lives cannot be realized in society (Jannah and Nawir, 2018)

For this reason, efforts are needed to change the paradigm of exclusive education towards a tolerant-inclusive paradigm of religious education. A spiritual teaching model that only emphasizes the truth of its religion must inevitably be 'dismantled'. It is because an exclusive and intolerant way of understanding theology will, in turn, destroy the harmony of religions and eliminate attitudes to respect each other's truths from other religions. One way to internalize prophetic values in pesantren is by organizing religious education with the perspective of transcendence, humanism, and liberalization.

1. Introducing the concept of "liyan" or the other in the context of social life through discussions with people of other religions

Pesantren An Najah Purwokerto has a regular schedule, namely discussions with people of other religions. Not infrequently presenting other religious leaders, this is to instil Islam's recognition, which means that students must understand religious pluralism. Some of the activities carried out by Pesantren An Najah related to the introduction of "liyan" are as shown in the following table 1:

Table 1. The activities carried out by pesantren an najah related to the introduction of "liyan".

\begin{tabular}{|c|c|c|c|}
\hline No. & Date & Activity & Description \\
\hline \multirow[t]{5}{*}{1.} & October & Temu SOBAT & Sobat attended approximately \\
\hline & 18-19, & Central Java- DIY & from elements of Islam, \\
\hline & 2017 & in Banyumas & Christianity, \\
\hline & & & $\begin{array}{l}\text { Catholicism, Confucianism, and followers of } \\
\text { faith from various parts of Central Java and }\end{array}$ \\
\hline & & & $\begin{array}{l}\text { Yogyakarta. This activity grounded the values } \\
\text { of Pancasila because different religious } \\
\text { backgrounds mingled in intimacy and } \\
\text { togetherness. This activity is an effort to create } \\
\text { a safe, peaceful, and prosperous Indonesia. }\end{array}$ \\
\hline 2. & November & The visit of & The purpose of the Susteran Junior High School \\
\hline & 6,20 & $\begin{array}{l}\text { Susteran Junior } \\
\text { High School }\end{array}$ & $\begin{array}{l}\text { students' visit is to know how the pesantren is, } \\
\text { the students' daily activities, and carry out each }\end{array}$ \\
\hline
\end{tabular}




\begin{tabular}{|c|c|c|c|}
\hline No. & Date & Activity & Description \\
\hline \multirow{11}{*}{3.} & \multirow{11}{*}{$\begin{array}{l}\text { December } \\
17,2017\end{array}$} & Purwokerto to the & subject teacher's duties such as musicalization \\
\hline & & Pesantren An & of poetry. If runs with creativity, is active and \\
\hline & & Najah & full of cooperation between each other, the \\
\hline & & Purwokerto & friendship is harmonious with each other; no \\
\hline & & 85 Christian & These visit activities are routinely carried out to \\
\hline & & students from & maintain friendship and have discussions with \\
\hline & & Djendral & students at Pesantren An Najah. The reality of \\
\hline & & Soedirman & diversity is close to religious ideals, and some \\
\hline & & University visited & are contrary to spiritual teachings. Therefore, \\
\hline & & Pesantren An & it's hoped this visitation activity can foster \\
\hline & & Najah & peace among religious communities \\
\hline \multirow[t]{5}{*}{4.} & \multirow{5}{*}{$\begin{array}{l}\text { August 1, } \\
2017\end{array}$} & The visit of 50 & This activity discusses conflicts that occur based \\
\hline & & $\begin{array}{l}\text { Catholic youths } \\
\text { from Japan and }\end{array}$ & $\begin{array}{l}\text { on SARA; he ensures that the disagreement } \\
\text { originates from inadequate communication }\end{array}$ \\
\hline & & Thailand to & between religions or tribes. The miss- \\
\hline & & Pesantren An & communication made it difficult for them to \\
\hline & & Najah & $\begin{array}{l}\text { understand each other. In Islam, there are the } \\
\text { teachings of Sufism which must have an open } \\
\text { association with people from various religious } \\
\text { backgrounds }\end{array}$ \\
\hline \multirow[t]{5}{*}{5.} & \multirow{5}{*}{$\begin{array}{l}\text { November } \\
18,2017\end{array}$} & The visit of 6 & The purpose of the six Frater visit was to \\
\hline & & Frater Catholic to & understand Islam's firsthand, the religion that \\
\hline & & Pesantren An & most of the Indonesian population adheres to. \\
\hline & & Najah & The majority of Indonesia is Muslim and still \\
\hline & & Purwokerto & $\begin{array}{l}\text { chooses to maintain an Indonesian state with } \\
\text { the Pancasila ideology. The role of ulama and } \\
\text { society is essential for establishing the Republic } \\
\text { of Indonesia, which cannot compete against } \\
\text { and divide by anyone. }\end{array}$ \\
\hline \multirow[t]{5}{*}{6.} & \multirow{5}{*}{$\begin{array}{l}\text { May 20, } \\
2017\end{array}$} & Dialogue Centre & In this forum, they formulate and create peace \\
\hline & & Universitas Islam & with a sharing model. To spread peace viruses \\
\hline & & Negeri (UIN) & to create religious harmony in an atmosphere of \\
\hline & & Sunan Kalijaga & calm. \\
\hline & & Yogyakarta & \\
\hline \multirow[t]{5}{*}{7.} & \multirow{5}{*}{$\begin{array}{l}\text { December } \\
16,2017\end{array}$} & Dialog of Unsoed & This activity is routinely carried out using a \\
\hline & & Christian Student & discussion method between Christian students \\
\hline & & Harmony and & and santri. To create intimacy between them, \\
\hline & & Santri Pesantren & even though they are of different religions. \\
\hline & & $\begin{array}{l}\text { An Najah } \\
\text { Purwokerto }\end{array}$ & \\
\hline \multirow{3}{*}{8.} & \multirow{3}{*}{$\begin{array}{l}\text { December } \\
18,2018\end{array}$} & The visit of 8 & This visit was carried out with students staying \\
\hline & & $\begin{array}{l}\text { catholic students } \\
\text { to Pesantren An } \\
\text { Naiah }\end{array}$ & $\begin{array}{l}\text { at the pesantren for two days to make students } \\
\text { experience life in the pesantren, mingling with } \\
\text { the students, getting closer to the reality of }\end{array}$ \\
\hline & & Purwokerto & $\begin{array}{l}\text { diversity to build brotherhood, even though } \\
\text { they have different beliefs. }\end{array}$ \\
\hline 9. & April 9, & Dialogue of & The issue of choice in political life that exists on \\
\hline & 2019 & $\begin{array}{l}\text { Interfaith Figures } \\
\text { at Pesantren An }\end{array}$ & $\begin{array}{l}\text { the part of the parties is trying to bring up } \\
\text { religion in the contestation of a democratic }\end{array}$ \\
\hline
\end{tabular}




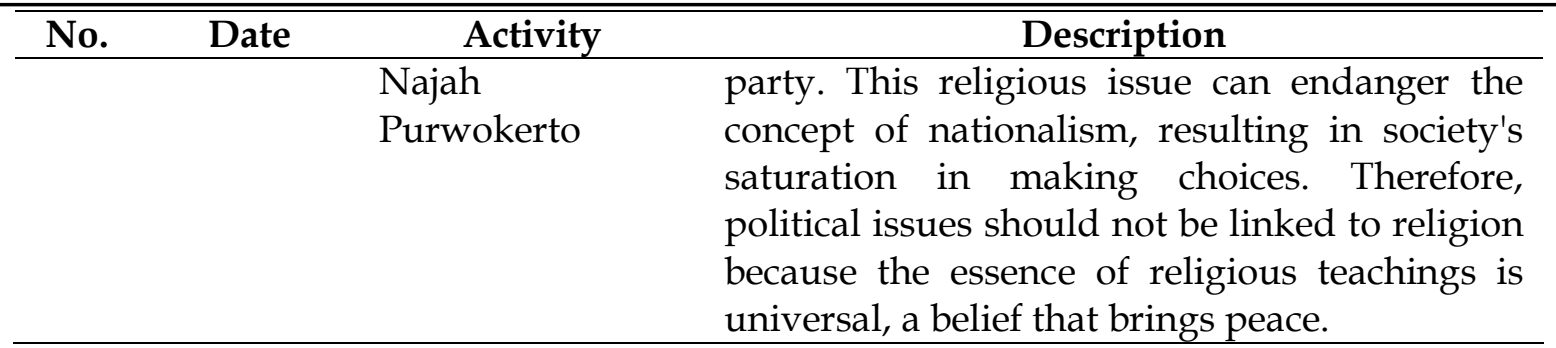

2. Grounding the sense of nationalism "hubbul wathan" through the commemoration of Indonesian Independence Day

The raising of the values of nationalism can have a very positive impact on life. One of them is reducing social conflicts that occur in social and state life. By applying the value of nationalism, society will find it easier to resolve social disputes in social life (Muniroh, 2018). There will also be a high tolerance attitude to accept the differences in culture and customs that apply in every community group, organization, religious community, and other community groups (Rozi, 2018). The differences that exist are not something that must be used as a conflict but must be used as a unifying nation and a characteristic of a harmonious country and can live side by side with existing differences .

As a means of instilling nationalism, every August 17, Pesantren An Najah holds a flag ceremony to commemorate Indonesia's independence day. Through this habituation, Pesantren An Najah students are equipped with nationalism to grow in their hearts continually. So that in looking at the differences that exist in life does not necessarily make it an excuse to be hostile; on the contrary, it becomes an encouragement to unite in the auspices of the Republic of Indonesia.

3. The application of Peace Education

In grounding the prophetic spirit, Pesantren An Najah implements peace education. It is done to equip students to prioritize harmony and peace in social life under any circumstances. This awareness considers that the deradicalization of terrorism among pesantren, especially students, can be through peace-based Islamic education or better known as peace education. In the last five years, the peace education discourse in Indonesia has been animated by the subject of multiculturalism and pluralism following the rampant incidents of violence with religious backgrounds, both between religions and followers of the same faith and issues of terrorism and radicalism (Muslihah, 2014).

Peace education, according to Zamroni, is a form of human empowerment with skills, behaviour and knowledge which includes the following: (1) building, enforcing and improving relationships at all levels of human interaction; (2) developing positive approaches to resolving conflicts, starting from personal to international; (3) creating a safe environment, both physically and emotionally, that all individuals need; and (4) sustainably build a safe environment and protect it from exploitation and war (Muslihah, 2014).

Today, one of the things that makes a country chaotic is hoaxes scattered on social media that make society noisy (Juditha, 2018). Some of them lead to radicalism or religious fundamentalism attitudes, which led to the threat of division. For this reason, Pesantren An Najah provides its students with the knowledge to filter all the information they get. Santri should prioritize the tabayyun attitude towards all news or information they receive. To at least not be part of the people who make a riot. 
For this reason, Pesantren An Najah Purwokerto welcomes the Purwokerto diocese to hold a Workshop Tangkal Berita Hoax. The event took place on August 1920, 2017 at the Siti Aisyah Pesantren An Najah Purwokerto Hall. Around 100 participants attended, from students, parishes from several cities in Central Java, Purwokerto Youth Catholic, G.P. Ansor, and the Gusdurian Community.

4. Local Culture-Based Education

Pesantren An Najah is the only pesantren in Purwokerto that applies local culturebased education and includes it in the educational curriculum. Prophetic education will be recognized and carried out consequently if it is able to dialogue with local cultures that have their respective local wisdom (Roqib, 2016).

In this regard, Pesantren An Najah presents local culture by introducing traditional medicine in learning and the collaboration between the Pesantren and Banyumasan-The Islam-Javanese dialogue produces local wisdom or traditional wisdom, which is an insight that contains Javanese wisdom in overcoming life problems. This traditional wisdom usually comes from the inner insights of scholars, who have intersected with Islamic and Javanese values (Roqib, 2016) -culture in the pesantren event every two years. Through formal medicine learning, students are expected to take local wisdom from existing cultures in society. Academically, there may not be a natural correlation, but it makes students more sensitive to cultural issues from a perspective.

Meanwhile, as we know, culture has a wealth of reasonable values for an inclusive understanding of life and life (Rahadi, 2017). It shows by introducing local culture in tradition or ritualistic culture such as the cowongan performance-Cowongan is a type of ritual or ceremony to ask for rain carried out by people in the Banyumas area and its surroundings. According to the belief of the Banyumas people, the request for rain through cowongan is carried out with the help of an angel, Dewi Sri who is the goddess of rice, a symbol of prosperity and prosperity. Through prayerful prayers, Dewi Sri will come through the arc of the rainbow (rainbow) towards the earth to bring down the rain. The arrival of rain means the coming of divine grace which is the source of life for all earthly creatures, including humans-in the Pesantren An Najah Purwokerto routine agenda, namely on the cultural stage, teaching or introducing religious positions with complementary cultures. This understanding minimizes the religious fundamentalism that has been rife recently (Djamal, 2018).

It is done with the awareness that pesantren represent cultural traditions that transcend social groups' boundaries, even though sometimes these traditions are also represented by groups that perfectly support the cultural ideals (Tamam, 2015). In Javanese terminology, we recognize many words that show how vital education makes people waskita, wicaksana, wirya, and sampurna. Words like Kawaskitan, kawicaksanan, kawiryan, and kasampurnan are attributes of perfect personalities, one of the leadership conditions. The quality of character is not a skill or expertise of a profession but a general requirement for civilized Javanese "Javanese". It shows that our culture prioritizes education, leading students to become human beings who uphold good manners and personality traits (Ridlwan, 2013).

Education will not leave culture because culture becomes the fundamental driving force of education, or in other terms, culture becomes the basis for teaching (Djamal). The educational process at school and outside of school becomes a seeding place for culture. This cultural form results from the human initiative, creativity and work that 
Prophetic Education at Pesantren As A Efforts To Prevent Religious Radicalism

always brings changes to human life, both in education, industry and social life (Ngafifi, 2014).

\section{CONCLUSIONS}

Today's religious radicalism or fundamentalism causes many conflicts in society. A superficial understanding of religious texts is suspected of being a triggering factor for the community's sensitivity in viewing religion. So, it is not surprising, if something is related to religion and there is an issue that tends to discredit, the community immediately responds with variations, where most are provoked by contradictory narratives that cause problems in a heterogeneous society. Thus, an educational formula is needed to provide not only knowledge but also substantive values regarding religion. So that people will mature in seeing the differences that exist, especially regarding religion. In this regard, pesantren is an educational alternative expected to provide answers, namely through prophetic education. Education is based on the values of transcendence, humanism, and liberation. So that religious education does not just stop at dogmatic issues, but also how religion can be a harmonious life source. Pesantren An Najah Purwokerto is a prophetic pesantren because it implements a curriculum based on prophetic values. Some of the steps taken by Pesantren An Najah Purwokerto in grounding prophetic content to its students are (1) Introducing the concept of "liyan" or the other in the context of social life through discussions with members of other religions; (2). Grounding the rationales of "hubbul wathan" nationalism. Through the commemoration of Indonesia's Independence Day; (3). Implementing Peace Education; and (4). Local Culture-Based Education. This research has tried to explain the theoretical concept of prophetic education and the realm of practice in the pesantren's life, which then transforms the pesantren into a prophetic pesantren. The portrait of the implementation of prophetic education, which is the breath of Pesantren An Najah Purwokerto, seems to be juxtaposed with prophetic education in Islamic boarding schools or other Islamic educational institutions. The reason is simple; Pesantren An Najah is nurtured by a Kyai who is also an academic and even the author of the book Prophetic Education. It means that theoretically, the caregivers of Pesantren An Najah are already knowledgeable. For this reason, if there is further research comparing the portrait of prophetic education in other pesantren, we will be seen the prophetic dimensions that exist in each pesantren.

\section{REFERENCES}

Ainiyah, N., \& Wibawa, N. H. H. P. (2013). Pembentukan karakter melalui pendidikan agama Islam. Al-Ulum, 13(1), 25-38.

Akmansyah, M. (2016). Tujuan pendidikan rohani dalam perspektif pendidikan sufistik. Ijtimaiyya: Jurnal Pengembangan Masyarakat Islam, 9(1), 91-108. https://doi.org/10.24042/ijpmi.v9i1.851

Alim, N., Pairin, P., Ikhsan, M., Samrin, S., \& Syamsuddin, S. (2018). Singularitas agama: Identifikasi aliran dan paham radikal di Kendari. Al-Ulum, 18(2), 271-300. https://doi.org/10.30603/au.v18i2.487

Alkatiri, W. (2018). Religious extremism di era post-everything. Akademika.

Anis, A. (2016). Al-Khawarij dan al-murjiah (sejarah timbulnya dan pokok-pokok ajarannya). Jurnal Mimbar: Media Intelektual Muslim Dan Bimbingan Rohani, 2(1), 26-41. https://doi.org/10.47435/mimbar.v2i1.280

Asrori, A. (2015). Radikalisme di Indonesia: Antara historisitas dan antropisitas. Kalam, 9(2), 253268. https://doi.org/10.24042/klm.v9i2.331 
Djamal, M. (2018). Pendidikan dan rekonstruksi budaya. Jurnal Pendidikan Surya Edukasi (JPSE), 4(1), 48-61. https://doi.org/10.37729/jpse.v4i1.4894

Eriyanto, M. G., Roesminingsih, Soedjarwo, \& Soeherman, I. K. (2021). The effect of learning motivation on learning independence and learning outcomes of students in the package C equivalence program. IJORER: International Journal of Recent Educational Research, 2(4), 455-467. https://doi.org/10.46245/ijorer.v2i4.122

Fauzi, F. (2018). Problem doktrin relativisme (studi kritis pemikiran cendekiawan muslim Indonesia). Tasfiyah: Jurnal Pemikiran Islam, 2(2), 245-270. https:// doi.org/10.21111/tasfiyah.v2i2.2576

Fuad, A. Z. (2014). Taksonomi transenden (paradigma baru tujuan pendidikan Islam). Jurnal Pendidikan Agama Islam (Journal of Islamic Education Studies), 2(1), 1-25. https:// doi.org/10.15642/jpai.2014.2.1.1-25

Haryanto, J. T. (2016). Radikalisme dan kebangsaan. Arti Bumi Intaran.

Indianto, D. (2019). Pitutur luhur. Pustaka Senja.

Jannah, S. M., \& Nawir, M. (2018). Harmonisasi agama (studi kasus koeksistensi umat beragama di kecamatan Lamasi kabupaten Luwu). Equilibrium: Jurnal Pendidikan, 6(2), 133-140. https://doi.org/10.26618/equilibrium.v6i2.2595

Juditha, C. (2018). Hoax communication interactivity in social media and anticipation (interaksi komunikasi hoax di media sosial serta antisipasinya). Jurnal Pekommas, 3(1), 31-44. https://doi.org/10.30818/jpkm.2018.2030104

Khamid, N. (2016). Bahaya radikalisme terhadap NKRI. Millati: Journal of Islamic Studies and Humanities, 1(1), 123-152. https:// doi.org/10.18326/mlt.v1i1.123-152

Masduqi, I. (2013). Deradikalisasi pendidikan Islam berbasis khazanah pesantren. Jurnal Pendidikan Islam, 2(1), 1-20. https:// doi.org/10.14421/jpi.2013.21.1-20

Miftahulloh. (2017). Pendidikan profetik perspektif moh. roqib dan implikasinya dalam rekonstruksi pendidikan islam integratif. IAIN Purwokerto.

Mu'awwanah, N. (2018). Konstruksi pemahaman masyarakat terhadap hadis "kullu bid'atin dlalalah". Jurnal Studi Ilmu-Ilmu Al-Qur'an Dan Hadis, 17(2), 159-186. https://doi.org/10.14421/qh.2016.1702-01

Muniroh, N. (2018). Implementasi nilai nasionalisme dan gotong royong dalam mata pelajaran pkn di MI pabelan dan MI miftahun najihin kecamatan Pabelan kabupaten semarang tahun pelajaran 2017/2018. Skrispi. IAIN Salatiga.

Muslihah, E. (2014). Pesantren dan pengembangan pendidikan perdamaian studi kasus di pesantren an-nidzomiyyah labuan pandeglang Banten. Analisis: Jurnal Studi Keislaman, 14(2), 311-340. https://doi.org/10.24042/ajsk.v14i2.693

Najib, F. A., \& Humaidi, H. (2020). Nasionalisme dalam Al-Qur'an (analisis kontektual abdullah saeed). Al-Insyiroh: Jurnal Studi Keislaman, 6(1), 70-83. https://doi.org/10.35309/alinsyiroh.v6i1.3817

Naupal, N. (2014). Klaim kebenaran teologi dan tuntutan zaman: Refleksi kritis atas etika beragama. KALAM, 8(2), 255-280. https:// doi.org/10.24042/klm.v8i2.303

Ngafifi, M. (2014). Kemajuan teknologi dan pola hidup manusia dalam perspektif sosial budaya. Jurnal Pembangunan Pendidikan: Fondasi Dan Aplikasi, 2(1), 33-47. https://doi.org/10.21831/jppfa.v2i1.2616

Rahadi, D. R. (2017). Perilaku pengguna dan informasi hoax di media sosial. Jurnal Manajemen dan Kewirausahaan, 5(1), 58-70. https://doi.org/10.26905/jmdk.v5i1.1342

Ridlwan, M. (2013). Revitalisasi peran profetik pesantren dalam membendung radikalisme agama. Al Hikmah: Jurnal Studi Keislaman, 3(1), 2-2. https://doi.org/10.36835/hjsk.v3i1.364

Rizqa, H. (2020, March 27). Beragama itu mudah, jangan mempersulit diri. Republika Online.

Rodin, D. (2016). Islam dan radikalisme: Telaah atas ayat-ayat "kekerasan" dalam al-Qur'an. Addin, 10(1), 29-60. https://doi.org/10.21043/addin.v10i1.1128 
Roqib, M. (2016). Filsafat pendidikan profetik. Pesantren An Najah Press.

Rozi, M. A. F. (2018). Implementation of prophetic education in islamic boarding school (pesantren). Edukasi: Jurnal Pendidikan Islam (e-Journal), 6(1), 140-161. https://doi.org/10.5281/edukasi.v6i1.330

Tamam, B. (2015). Pesantren, nalar dan tradisi. Pustaka Pelajar.

Wajdi, M., Nurdiyanti, \& Amir, N. (2021). Improving students' motivation and learning outcomes using edmodo learning media assisted with meeting room media on the circulation system materials. IJORER: International Journal of Recent Educational Research, 2(4), 392-401. https://doi.org/10.46245/ijorer.v2i4.119

Widiyanto, D. (2017). Pembelajaran toleransi dan keragaman dalam pendidikan pancasila dan kewarganegaraan di sekolah dasar. Prosiding Konferensi Nasional Kewarganegaraan, 3(1), 109-115.

Zaini, A. H. F. (2018). Nasionalisme kaum sarungan. Kompas Gramedia Utama.

\footnotetext{
*Dimas Indianto S

Department of Education Faculty,

Prof. KH. Saifuddin Zuhri State Islamic University Purwokerto,

Jl. Ahmad Yani 40A, Purwokerto, Center of Java, 53126, Indonesia

Email: $\underline{\text { dimas@iainpurwokerto.ac.id }}$

Sunhaji

Department of Education Faculty,

Prof. KH. Saifuddin Zuhri State Islamic University Purwokerto,

Jl. Ahmad Yani 40A, Purwokerto, Center of Java, 53126, Indonesia

Email: sunhaji@iainpurwokerto.ac.id

\section{Intan Nur Azizah}

Department of Education Faculty,

Prof. KH. Saifuddin Zuhri State Islamic University Purwokerto,

Jl. Ahmad Yani 40A, Purwokerto, Center of Java, 53126, Indonesia

Email: intannur@iainpurwokerto.ac.id

\section{Akhmad Roja Badrus Zaman}

Department of Post-graduate School,

Sunan Kalijaga State Islamic University Yogyakarta,

Jl. Laksda Adisucipto, Caturtunggal, Depok, Sleman, Yogyakarta, 55281, Indonesia

Email: $\underline{\text { badruszamana@gmalil.com }}$
} 